\title{
Discourse Analysis of Lord of the Flies: A Systemic Functional Approach
}

\author{
Tianyue Wang \\ School of Foreign Languages and Cultures, Nanjing Normal University, Nanjing, China \\ Email: wtychristina19@126.com
}

How to cite this paper: Wang, T. Y. (2021). Discourse Analysis of Lord of the Flies: A Systemic Functional Approach. $A d$ vances in Literary Study, 9, 114-126. https://doi.org/10.4236/als.2021.93013

Received: April 30, 2021

Accepted: May 29, 2021

Published: June 1, 2021

Copyright $\odot 2021$ by author(s) and Scientific Research Publishing Inc. This work is licensed under the Creative Commons Attribution International License (CC BY 4.0).

http://creativecommons.org/licenses/by/4.0/

\begin{abstract}
This study used a systemic functional linguistic approach to interpret the theme of Lord of the Flies, an allegorical novel written by British writer William Golding. On the basis of the clause, this research analyzed the author's ways of writing and interpreted the functional meanings he tried to convey through the wording and structure of the novel. Excerptions from Lord of the Flies were analyzed in terms of the three metafunctions of language, namely, ideational function, interpersonal function, and textual function. More specifically, the current study focused on the author's lexico-grammatical choices in the transitivity system, mood system, and thematic structure of the clauses and revealed that different choices encode different meanings, all contributing to the manifestation of the theme: without proper constraints, human's inner evil will be magnified indefinitely and their reversion to savagery will be inevitable.
\end{abstract}

\section{Keywords}

Lord of the Flies, Systemic Functional Approach, Metafunctions, Literature Analysis

\section{Introduction}

Lord of the Flies, published after World War II, was written by British writer William Golding. Lord of the Flies tells the story of several groups of boys who were left on an isolated island during the evacuation from an atomic war and depicts their harrowing reversion to savagery. It is an influential philosophic fiction in that the characters and their behaviors are all highly symbolized. It serves the theme of revealing the inner evil of humanity and reveals people's agitation towards the war. In order to achieve objective analysis of this literature, the current research adopted the systemic functional linguistic approach to examine the 
wording and structure of some representative excerptions from the book.

Since the publication of Lord of the Flies in 1954, the novel has received much attention and intrigued many readers as well as literary critics. Extensive research of this novel has been conducted and vastly diversified in theory and methodology. But most of the existing investigation has been carried out from the perspective of traditional literary criticism such as the prototype theory, symbolism, sociology, binary opposition, etc. (e.g. Al-Saidi, 2012; Baker, 1966; Li, 1999; Mohammad \& Aldouri, 2011), which indeed has provided broad insights but also had some limitations such as subjectivity and obscurity derived from the personal preference and bias of the critics. Besides, despite the enthusiasm of studying Lord of the Flies, no existing research has focused on its linguistic aspect. The author surely used vivid and symbolized language to convey his own thoughts, so when trying to interpret this novel, it is important to take language into account. This study is the first attempt to apply Systemic Functional Grammar (SFG) to the research on this literature work. SFG focuses on the language structure of a text and the functions it serves, through which the stylistic effect can be demonstrated with maximum objectivity.

The systemic functional approach was initially proposed by a British linguist M. A. K. Halliday (1994). He regards language essentially as a medium of conveying meaning, organized as a system of choices. The purpose of language construction and dissemination from one source to another is to perform one or more functions among its users (Dalamu, 2017). Systemic Functional grammar specializes in discourse analysis (Bloor \& Bloor, 2004). A text is perceived as the unit of language performing a particular function in a particular environment, and SFG is seen as a tool for examining text. The basic unit of such examination is the clause, a composite entity (Ravelli, 2000). It consists of three dimensions of the structure, and each of them constructs a distinctive level of meaning, and the three strands of structures are realized through three highly codified and abstract metafunctions, known as ideational function, interpersonal function, and textual function. Focusing on some of the excerptions from the novel Lord of the Flies, the following sections will analyze how the use of certain words and constructions performs the three metafunctions respectively and how the three metafunctions work together to serve the ultimate theme of the novel.

\section{The Ideational Analyses}

The ideational function is used to convey new information unknown to the hearer. It states facts, describes actions and expresses emotions. Clauses in a text that perform the ideational function are actually conveying information about what is going on or what is happening. One main constituent of this function is "transitivity". Transitivity is a semantic system that dissects and categorizes the experience of people into six different processes (i.e. the material process, the mental process, the relational process, the verbal process, the behavioral process, and the existential process) and designates the participants and environment in 
each process. "Transitivity" will be tended to in this section due to its indispensable status in analyzing a story that involves several characters as well as descriptions of their behaviors and activities.

\subsection{Material and Behavioral Processes}

A material process is a process of doing things. It is about concrete actions (Eggins, 2004: p. 215) and typically includes an Actor (the agent that is responsible for his/her actions), a Goal (the recipient of actions), and an action verb. A behavioral process is in part about action, but it is an action that has to be experienced by one conscious being (Alaei \& Ahangari, 2016). Material and Behavioral processes used in a story are usually descriptions of activities of the characters.

In Lord of the Flies, there is a typical plot that serves as a turning point of the story and also a hint to what will happen to the boys:

He knelt, holding the shell of water. A rounded patch of sunlight fell on his face and a brightness appeared in the depths of the water.

He spilt the water and leapt to his feet, laughing excitedly. Beside the pool his sinewy body held up a mask that drew their eyes and appalled them. He began to dance and his laughter became a bloodthirsty snarling. He capered toward Bill.

The face of red and white and black swung through the air and jigged toward Bill.

The mask compelled them.

(Golding, 1954: p. 83)

These clauses are made up of material and behavioral processes that tell readers how Jack paints his face with colors and feels for the first time that the brutish side within him is awake. Third-person "he" is the Actor of most of these clauses and the corresponding action verbs such as "spilt" "leapt" "dance" "capered" all suggest brisk, exciting actions, indicating the release of his pent-up wildness. Other verbs such as "drew" "appalled" "compelled" take Jack's followers as Goals, suggesting that the sudden change of Jack both attracted them and scared them.

This plot implies very revealing meaning. The ways Jack acts and his friends react described by the material and behavioral processes symbolize that the painted face, as a mask, conceals the civilized humanity inside Jack and he becomes able to act like a completely different person-a savage under the "protection" of the mask. It also drops a hint that Jack would later develop into the leader of the uncivilized group.

\subsection{Mental and Verbal Processes}

A mental process is a process of sensing, which involves "perception (seeing, hearing)", "reaction (liking, fearing)", and "cognition (thinking, knowing, and understanding)" (Halliday, 1994: p. 118). The two participants in this process are "Senser" and "Phenomenon". A verbal process refers to the exchange of information which includes Sayer, Receiver, and Verbiage. 
Mental and verbal processes are interspersed in the book to help build up the characters. As much more mental processes can be found than verbal processes and the former does better in depicting the personality of the Senser, main focus will fall on the mental processes.

After the accident in which the boys missed an opportunity to be rescued because Jack led his whole group to hunt pigs in the forest and let the fire extinguish, Ralph, the leader of the civilized group, decided to call an assembly. He walked along the beach, preparing what he was going to say. The author used a lot of mental processes to show the mental activity of Ralph.

He found himself understanding the wearisomeness of his life.

At that he walked faster, aware all at once of urgency.

(Golding, 1954: pp. 101-102)

These two sentences perform a very important function of indicating Ralph, as the chief of all the boys, becomes aware that something is wrong and realizes that everything may go out of control if he does not intervene immediately.

With a convulsion of the mind, Ralph discovered dirt and decay (Phenomenon), understood how much he disliked perpetually flicking the tangled hair out of his eyes (Phenomenon).

(Golding, 1954: p. 102)

This sentence consists of two Phenomenons that are perceived by the Senser Ralph. The two Phenomenons represent the barbaric life on the island, which is strongly resented by Ralph. His attitude further proves that he is a firm supporter of the order and rules of modern society and he cannot bear the degeneration of civilization.

The trouble was, if you were a chief you had to think.

This made you think.

Only, decided Ralph as he faced the chief's seat, I can't think.

By myself I went, thinking what's what. I know what we need.

(Golding, 1954: pp. 104-105)

The first two sentences describe the direct activity in Ralph's mind, and the last sentence is the speech given by Ralph on the assembly. The repetitive occurrence of the verb "think" suggests that Ralph's role on the island is a thinker and a leader, although not a good one. He is a representative of the rational mind in that he has his own opinions and can make his own judgement. Furthermore, these sentences also reveal that he is a kind of idealist. In the story, he always worries too much about their existential state despite that almost no one else worries as he does. He sticks to the principles of human society but does not realize that the principles are not feasible on this deserted island, which implies his eventual tragic ending.

\subsection{Relational and Existential Processes}

Relational and existential processes are mostly used to describe the environment, to construct a social, cultural, or even psychological context of what is happening. They are also used to designate the properties or attributes of an object. A 
relational process is a process of being. It has two types: Attributive, which expresses what attributes an object has, and Identifying, which indicates the identical properties of two entities ( $\mathrm{Hu}, 2013)$. These two relations can be further dissected into Intensive ( $\mathrm{x}$ is a), Circumstantial ( $\mathrm{x}$ is at a), and Possessive ( $\mathrm{x}$ has a). An existential process is a process of existing or happening, which always includes an Existent. Lord of the Flies includes extensive environmental descriptions that suggest the current situation or the mental state of the characters.

The first rhythm that they became used to was the slow swing from dawn to quick dusk.

Toward noon, as the floods of lights fell more nearly to the perpendicular, the stark colors of the morning were smoothed in pearl and opalescence.

Sometimes land loomed where there was no land and flicked out like a bubble as the children watched.

When the sun sank, darkness dropped on the island like an extinguisher and soon the shelters were full of restless, under the remote stars.

(Golding, 1954: pp. 101-102)

These four sentences all include relational processes that are of Intensive type except for the third sentence which is of Circumstantial type. The sentences depict the environment and daily life of the boys when they gradually get used to the island. The beach is beautiful, fantastic, and undergoes various unpredictable changes during a day. The last sentence "darkness dropped on the island like an extinguisher and soon the shelters were full of restless" indicates in particular the boys' fear towards darkness, more specifically towards the unknown danger that lurks in the darkness. It also foreshadows the beast that will soon appear.

A steady current of heated air rose all day from the mountain and was thrust to ten thousand feet; revolving masses of gas piled up the static until the air was ready to explode. By early evening the sun had gone and a brassy glare had taken the place of clear daylight. Even the air that pushed in from the sea was hot (Relational) and held no refreshment. Colors drained from water and trees and pink surfaces of rock, and white and brown clouds brooded.

(Golding, 1954: p. 203)

This paragraph is constituted of most existential processes and one relational process, describing the scenery and weather conditions after Simon, who accidentally uncovered the secrets of the lord of the flies, lost his consciousness. These sentences vividly bring readers a sense of stifling depression through the choice of expressions such as "heated air" "explode" "no refreshment" "colors drained", etc. This is also the environment where the lord of the flies exists. The place, the unbearable temperature, together with the gradual arrival of dark night tint Simon's discovery with mysterious, unearthly colors and may also serve as an omen for Simon's death.

\section{The Interpersonal Analyses}

The interpersonal function refers to the function of using language to participate 
in social activities. Language is a meaningful activity and work method for social people ( $\mathrm{Hu}, 2013)$. It necessarily reflects the relationship between people. Therefore, it has the functions of expressing the speaker's identity, status, attitude, motivation, and his inference, judgment and evaluation of things. According to Halliday (1994: pp. 68-105), the interpersonal function is mainly realized by mood system, modality system and tone system. The mood system will be the focus of this section because it specializes in analyzing dialogues and utterances of characters, which are quite ubiquitous in this novel. Different mood types can be chosen to perform different speech functions. Statement is realized through declarative mood; question is realized through interrogative mood; command is associated with imperative mood; offer is associated with modulated interrogative mood. Mood is made up of Subject and Finite. Subject is usually the grammatical subject of a clause that is responsible for the exchanging function and Finite is part of the verb constituent (Hu, 2013). In this section, two important conversations from the book were selected and investigated in terms of the mood system.

\subsection{Mood Analysis of the Conversation between Simon and the Beast}

The first conversation was between Simon and the beast-lord of the flies, whose real identity was actually a sow's head occupied by swamps of flies. Simon had a fit and in his hallucination the lord of the files was talking to him. This conversation has an allegorical nature in that by virtue of the sow's head, the real purpose of the author writing such a story is revealed: human make the devil they fear with their own hands.

\subsubsection{Declarative Mood}

The declarative mood is used to state a fact or describe a state. It can be further divided into indicative mood and exclamatory mood.

This conversation is dominated by the lord of the flies. In fact, Simon only uttered one sentence "Pig's head on a stick." It was reasonable because at that time he lost most of his consciousness. Declarative sentences uttered by the lord of the flies were short but intimidating, some of which were exclamatory sentences with even stronger power.

"You are a silly little boy, just an ignorant, silly little boy."

"They think you are batty."

"There isn't anyone to help you. Only me. And I $m$ the Beast."

"Fancy thinking the Beast was something you could hunt and kill?"

"P m warning you. $1 \mathrm{~m}$ going to get angry."

(Golding, 1954: pp. 199-201)

These five sentences are all of indisputable firmness, aiming at confusing $\mathrm{Si}$ mon's mind. The lord of the flies first scorned Simon as an ignorant silly little boy, suggesting that those boys, or even all humans were too naive to understand their inner evil and that evil could easily control them. Then it tried to further 
disturb Simon by emphasizing other boys' indifference to him. Lord of the flies knew the vulnerable part in Simon's heart and kept attacking it. In the end its pretentiousness was exposed and it foretold that the island was going to be shrouded in cruelty and chaos.

\subsubsection{Interrogative Mood}

The common interrogative mood is usually used to get information from the hearer which takes the form of a question. Except for the common type of questions, there are also tag questions and rhetorical questions that bear special literary effects.

The first conversation contains many questions, especially tag questions. They were all used by the lord of the flies.

"Don't you agree? Aren't you just a silly little boy?"

"You don't want Ralph to think you' re batty, do you?"

"Aren't you afraid of me?"

"You knew, didn't you? I m part of you?"

"D' you see? You' re not wanted. Understand? We are going to have fun on this island. Understand?"

"We shall do you? See?"

(Golding, 1954: pp.200-201)

Rhetorical questions and tag questions are special kinds of interrogative sentences in that they are not for gaining information but for strengthening the point the speaker wants to make. The lord of the flies chooses question forms not to elicit responses from Simon but to threaten and to frighten him by appearing to be interactive. "You knew, didn't you? I m part of you?" is even more thought-provoking for it sounds like the lord of the flies is asking each one of the readers and pushing them to think. In all, these questions vividly depict the image of a crafty, creepy demon.

\subsubsection{Imperative Mood}

The imperative mood is used to direct or affect others' behaviors or psychological states. It is also an intensive way to express the speaker's feelings, judgement, or emotions. Both of the excerpted conversations involve very few imperative sentences but they are worth probing.

The first conversation contains imperative sentences as follows:

"You'd better run off and play with the others."

"Come now. Get back to the others and we'll forget the whole thing."

"You know perfectly well you'll only meet me down there-so don't try to escape?"

(Golding, 1954: pp. 200-201)

The first two sentences were used to lure Simon to go back to the boys but the third one stated the consequence if Simon did go back, which suggested that the lord of the flies existed in the hearts of the boys down the mountain. The author was wise to hide the theme-the nature of the lord of the flies-between a few 
short sentences and only when readers explore under the surface of the words can they really understand the story.

\subsection{Mood Analysis of the Conversation between Ralph and Piggy}

The second conversation took place between Piggy and Ralph after they took part in the carnival where the boys were caught up in a feverish dance and beat poor Simon to death. Both of them were afraid and did not want to admit that they helped kill Simon. The dialogue between the two boys who were originally representative of goodness tore off the mask covering the brutal truth: evil exists in every spirit.

\subsubsection{Declarative Mood}

This conversation is also rich in declarative sentences, which can be analyzed from different perspectives of the two speakers-Ralph and Piggy. Ralph's utterances were excerpted as follows:

"Piggy."

"That was Simon."

"Piggy."

"That was murder."

"I was-I don't know what I was."

"P m frightened. Of us. I want to go home. Oh God, I want to go home."

(Golding, 1954: pp. 219-220)

These utterances convey a very depressing mood. These short sentences use simple structures to connote strong emotions of the speaker. In the first four utterances, Ralph uttered each word slowly and clearly and the simple Subject-Verb-Object structure shows that Ralph was still in shock. He could not believe what they had done but deep down he knew the murder really happened. The last two utterances show his fear of what people were capable of, even though they were only young children. He for the first time realized that human could be their own enemies and killers. This epiphany was so overwhelming that he could hardly bear it.

Piggy's utterances are as follows:

"It was dark. There was that-that bloody dance. There was lightening and thunder and rain. We was scared?'

"We was scared! Anything might have happened. It wasn' - -what you said."

"It was an accident, that's what it was. An accident."

"He was batty. He asked for it. It was an accident."

"It was an accident, and that's that."

"They never noticed in the dark, Anyway you said I was only on the outside."

"We never done nothing, we never seen nothing."

(Golding, 1954: pp.199-221)

Unlike Ralph, he denied in the first place what they had done. He refused to believe that the boys could be monsters. The frequent repetition of "It was an accident" and "that's that" actually suggests his uncertainty and guilt although on the surface the assertions seem to be the emphasis of reality. When Piggy finally 
admitted the murder did happen, he began to evade responsibility by stressing that he did not do it on purpose and the possibility that they were not seen by others. These utterances also reveal the frailty in Piggy's characteristics: he refused to see the inner evil of people.

\subsubsection{Interrogative Mood}

There are not many questions and most of which were uttered by Ralph.

"What we going to do?"

"Call an assembly?"

"Don't you understand, Piggy? The things we did-"

"Didn't you see, Piggy?"

(Golding, 1954: pp. 218-220)

Again these questions showed the bewilderment of Ralph toward the terrifying sin the boys committed. He did not know what to do next and was in despair. The last two rhetorical questions suggested that initially he could not agree with Piggy's denying and escaping, which also indicate he is good in nature and serve as a contrast between him and Piggy.

\subsubsection{Imperative Mood}

This conversation contains only one imperative sentence:

"Don't let on we was in the dance. Not to Samneric."

(Golding, 1954: p. 220)

Normally, adopting imperative mood suggests the higher status of the speaker than that of the hearer so he or she can give orders or requests. But in the second conversation, though Ralph was supposed to be the chief, he was too weak at that time, so Piggy had to take control and forced Ralph to cover the fact that they had been in that dance too.

\section{The Textual Analyses}

The textual function is performed to give order to a text, to make a text wellorganized and coherent within themselves (Dai \& He, 2013). This function is realized through thematic structure and coherence. Thematic structure reveals how information is organized and arranged within a text, in which Theme refers to the known information shared by both the speaker/writer and the hearer/reader, while Rheme is the new knowledge that is to be conveyed (Halliday, 1994).

Another important concept that should be introduced is thematic progression, which refers to the process in which new information is promoted from known information, thus the new information becomes known information and then advances to proceeding new information. Linguists examined massive seemingly random texts and summarized from them the basic patterns of thematic progression (e.g. Danes, 1974: p. 108; Fries, 1983; Zhu, 1995), namely, constant theme progression, constant rheme progression, linear theme progression, and cross theme progression. Their definitions are as follows: 
1) Constant theme pattern: in a group of sentences, the theme of each sentence remains unchanged while triggers different rheme.

2) Constant rheme pattern: a group of sentences share the same rheme but different themes.

3) Linear theme pattern: the rheme of a former sentence becomes the theme of a following sentence.

4) Cross theme pattern: the theme of a former sentence becomes the rheme of a following sentence.

In this part, the focus will fall on the thematic structure and progression in that these two elements better serve the need of understanding how the author organize important plots to promote the development of the story. The following sections will identify the theme and rheme of each clause from the penultimate paragraph and then analyze the effects of such a structure. Then the pattern of thematic progression will be illustrated.

The excerpted paragraph is as follows:

Ralph looked at him dumbly. For a moment he had a fleeting picture of the strangle glamour that had once invested the beaches. But the island was scorched up like dead wood-Simon was dead-and Jack had... The tears began to flow and sobs shook him. He gave himself up to them now for the first time on the island; great, shuddering spasms of grief that seemed to wrench his whole body. His voice rose under the black smoke before the burning wreckage of the island; and infected by that emotion, the other little boys began to shake and sob too. And in the middle of them, with filthy body, matted hair, and unwiped nose, Ralph wept for the end of innocence, the darkness of man's heart, and the fall through the air of the true, wise friend called Piggy.

(Golding, 1954: p. 284)

The situation described in this paragraph was set after Ralph was found by a naval officer when he was hunted by Jack's group. Suddenly it seemed that all the fighting stopped and the boys could finally go home, but it was far from a happy ending. Through the sentence "Ralph wept for the end of innocence, the darkness of man's heart, and the fall through the air of the true, wise friend called Piggy", the author was clearly trying to suggest that things were not that simple. Being rescued was not the end of the war because even the officer himself represented the war, so the threat would never end as long as inner evil continued to exist.

\subsection{Thematic Structure Analysis}

By analyzing the above paragraph, the themes of all the clauses are as follows:

T1: Ralph

T2: He

T3: The island

T4: The tears

T5: Sobs

T6: He 
T7: Grief

T8: His voice

T9: The other little boys

T10: Ralph

From the above ten themes, the organization of the semantic elements in this paragraph is clearly observed: The author took the viewpoint of Ralph and focused on his feelings. He first directly described the current state of Ralph, his flashback of memory. Then Ralph thought of his onetime friends, who were either dead or changed into completely different people. Such a thought evoked strong grief in him and pushed his emotions to a zenith, which also infected other boys. From T4 to T8, the progression to climax is demonstrated. At the end the focus returns to Ralph's feelings, which also sublimates a children story into an allegory with rich implications. In the last sentence, the author appeared, and his warning to readers was put across through Ralph.

\subsection{Thematic Progression Analysis}

By dissecting the thematic structure of this short text, the thematic progression patterns can be inferred as in Figure 1.

From above, it is concluded that all four patterns of thematic progression have been used. Constant theme pattern was used six times; constant rheme pattern was used one time; linear theme pattern one time and cross theme pattern two times. The application of constant theme pattern indicates that there is a very clear subject (i.e. Ralph) and the text is organized around him. T1 appears most times, which again proves that Ralph is the focus and this paragraph is all about what he saw and what he felt. So all the information in this paragraph is radiated from the central character.

\section{Conclusion}

Through the application of functional linguistic analysis on the author's choices of words and structures, this research has reached a better understanding of the most famous work of William Golding-Lord of the Flies. Ideational analysis described the mental and physical behaviors of main characters in the book and

$$
\begin{gathered}
\mathrm{T} 1-\mathrm{R} 1 \\
\mathrm{~T} 2(=\mathrm{T} 1)-\mathrm{R} 2 \\
\mathrm{~T} 3(=\mathrm{R} 2)-\mathrm{R} 3 \\
\mathrm{~T} 4(=\mathrm{T} 2)-\mathrm{R} 4 \\
\mathrm{~T} 5(=\mathrm{T} 2)-\mathrm{R} 5 \\
\mathrm{~T} 6(=\mathrm{T} 2)-\mathrm{R} 6 \\
\mathrm{~T} 7-\mathrm{R} 7(=\mathrm{T} 6) \\
\mathrm{T} 8(=\mathrm{T} 7)-\mathrm{R} 8(=\mathrm{T} 3) \\
\mathrm{T} 9-\mathrm{R} 9 \\
\mathrm{~T} 10(=\mathrm{T} 8)-\mathrm{R} 10
\end{gathered}
$$

Figure 1. The thematic progression pattern of the penultimate paragraph. 
revealed how these behaviors show their dispositions. It also took environmental descriptions into account and figured out the significance of such descriptions in motivating the development of the plot. Interpersonal analysis revealed what was hiding behind the communications of the characters and portrayed their personalities. The textual analysis focused on the texture of the novel and the techniques used by the author to organize the story. The three metafunctions are encoded in three dimensions of discourse, namely, narration, dialogue, and texture that together construct the complete representation of a story. Through all these analyses, the author's purpose in writing such an allegory becomes clearer. He tried to demonstrate the process of the moral degeneration of civilized people, making his point that without constraints and sanctions, reversion to savagery will definitely take place. He vividly depicted the inherent evil of humanity, not being pessimistic, but trying to warn people to remain vigilant about the savage instincts lurking within everyone.

\section{Acknowledgements}

This research was supported by the Postgraduate Research \& Practice Innovation Program of Jiangsu Province (KYCX20_1221).

\section{Conflicts of Interest}

The author declares no conflicts of interest regarding the publication of this paper.

\section{References}

Alaei, M., \& Ahangari, S. (2016). A Study of Ideational Metafunction in Joseph Conrad's "Heart of Darkness": A Critical Discourse Analysis. English Language Teaching, 9, 203-213. https://doi.org/10.5539/elt.v9n4p203

Al-Saidi, A. (2012). Savagery and the Heart of Darkness in William Golding's Lord of the Flies. Studies in Literature \& Language, 4, 129-134.

Baker, J. R. (1966). William Golding: A Critical Study. New York: SF Martin's Press.

Bloor, T., \& Bloor, M. (2004). The Functional Analysis of English. London: Hodder Arnold. https://doi.org/10.4324/9780203774854

Dai, W. D., \& He, Z. X. (2013). A New Concise Course in Linguistics for Students of English. Shanghai: Shanghai Foreign Language Education Press.

Dalamu, T. A. (2017). Systemic Functional Theory: A Pickax of Textual Investigation. International Journal of Applied Linguistics \& English Literature, 6, 187-198. https://doi.org/10.7575/aiac.ijalel.v.6n.3p.187

Danes, F. (1974). Functional Sentence Perspective and the Organization of the Text. In F. Danes (Ed.), Papers in Functional Sentence Perspective (pp. 106-128). Prague: Academia. https://doi.org/10.1515/9783111676524

Eggins, S. (2004). An Introduction to Systemic Functional Linguistics (2nd ed.). New York: Continuum International Publishing Group.

Fries, P. (1983). On the Status of theme in English. In J. S. Petofi, \& E. Sozer (Eds.), Micro- and Macro-Connexity of Discourse. Hamburg: Buske. 
Golding, W. (1954). Lord of the Flies. New York: Penguin Group.

Halliday, M. A. K. (1994). Introduction to Functional Grammar (2nd ed.). London: Arnold.

Hu, Z. L. (2013). Linguistics: A Course Book. Beijing: Beijing University Press,

Li, Y. H. (1999). Devoid of Childishness, Devoid of Humanity: On Reading Lord of the Flies by Golding. Foreign Literature Studies, 1, 83-87.

Mohammad, K. K., \& Aldouri, A. H. (2011). Understanding of Humanity a Study in: William Golding's Lord of the Flies. Tikrit University Journal for Humanities, 18, 615-627.

Ravelli, L. (2000). Getting Started with Functional Analysis of Texts. Researching Language in Schools and Communities, 1, 27-63.

Zhu Y. S. (1995). Thematic Progression Patterns and Discourse Analysis. Foreign Language Teaching and Research, 3, 6-12. 